\title{
Migration, Identity and Belonging
}

\author{
Mary Gilmartin* \\ Department of Geography, National University of Ireland Maynooth
}

\begin{abstract}
The study of migration within geography takes a variety of forms. While geographers traditionally studied push and pull factors in migration, this approach was challenged for its reliance on quantitative methods and its emphasis on economic factors. New approaches to the study of migration in geography have thus incorporated qualitative techniques and focused on migrant identities and migrant subjectivities. They have also provided new theorizations of the relationship between mobility and belonging, particularly through the concepts of transnationalism and translocalism, and through scales of belonging that range from citizenship to the home. Despite claims of the demise of the nation-state under globalization, the role of the nation-state in regulating migration and migrants, and in managing and policing borders, highlights its ongoing importance. Similarly, the potential centrality of place to the ongoing study of migration is highlighted by recent research on cities and regions. This foregrounds the negotiated and mutable nature of place in the context of transformations at a variety of interconnected scales.
\end{abstract}

\section{Introduction}

Leabhar Gabhála (the Book of Invasions) is often described as a myth of origin for people living in Ireland. Like many other myths of origin, it focuses on migrants: on the various groups who, at different times, moved to Ireland, transformed it, fought for it, and made it their home. The travels and arrivals of the Fir Bolg, the Tuatha de Danann, the Milesians and other invaders were inscribed in Leabhar Gabhála, and the book was regularly revised, expanded and translated from its first appearance in the 12 th century. The most recent version, from the 17 th century, was rediscovered in Berlin in the 1980s. It had probably been brought to Louvain in Belgium in 1637, following the path to exile taken by the Gaelic chieftains of Ulster a few decades earlier. In this way, Leabhar Gabhála, with its stories of migrations, is itself part of an ancient circuit of migrations of people, objects and ideas.

Centuries after Leabhar Gabhála was first put to paper, writer Rebecca Solnit (1998) used it as an anchor for her book on travels around Ireland. Solnit (1998) thought that Ireland - with its long history of invasion and 
exile - would be an excellent site to explore the interplay between 'memory, identity, movement and landscape' (p. 7). Though American by birth, Solnit had recently acquired an Irish passport by virtue of migrant great grandparents. 'I'm not much of an Irishwoman', she admitted, expressing amazement that 'so thin a mythological fluid as blood entitled me to so solid a legal status as citizenship' (Solnit 1998, 6). Her personal story, returning as a citizen to the place her great grandparents had left as emigrants, points to the ever-shifting nature of the relationship between mobility, identity and place. Since Solnit wrote her account of travels in Ireland, the country has experienced another chapter in its story of migration. The families of returning Irish emigrants, migrants from older and newer European countries, labour migrants from Asia, Africa and the Americas, students, asylum seekers and refugees have increased the foreign-born population in Ireland from 5.6\% in 1991 to over 13\% in 2006. The dramatic change has led to new articulations of the relationship between identity and place in Ireland. In particular, it has led to new attempts to define belonging in contemporary Ireland, changing the meaning of citizenship, and creating new categories of migrants with different rights and entitlements.

These different moments - the long history of migration, the relationship between identity, place and mobility, and the practice and politics of belonging - provide a signpost to the ways in which geographers attempt to make sense of migration and its relationship to identity and to place. In this article, I outline these various approaches to the study of migration within geography, paying particular attention to recent developments. The recent appeal of transnationalism has led to a focus on migrants as its embodiment. The resulting replacement of cause with effect as the focus for geographical studies of migration may serve to enrich our understanding of migrant identities. However, in its richness of detail, it often detracts attention from other, equally important aspects of migration: the political economy of migration, the interconnections between state and capital, the relationship between richer and poorer parts of the world, the power of elites and the romanticization of hybridity and mobility. The challenge, for geographers studying migration, is to understand the complexities of these relationships in and across places and scales.

\section{Pulled and Pushed: The Geographies of Populations}

Push and pull factors frame many students' initial engagement with migration. They provide apparently straightforward answers to obvious questions. Why do people leave a particular area? The answers may include poverty, lack of economic opportunity, conflict and economic disruption. Why do people move to a particular area? Possible answers include job opportunities, the prospect of wealth, or to join family and friends already there. The move from one particular area to another is often explained in terms of 
relative opportunity. Dorigo and Tobler (1983) described it as the difference between dissatisfaction at the origin and expected satisfaction at the destination (p. 4). In many ways, much of the work on push and pull factors harks back to an early attempt to systematize the study of migration. Writing in 1885, Ernest Ravenstein (1885) had outlined his laws of migration, suggesting that migrants are more likely to move to areas of economic opportunity (p. 199).

Given the apparent straightforwardness of this approach, why, then, does it now raise the suspicions of many geographers studying migration? A first reason is its emphasis on economics and on economic determinants. In other words, push and pull factors are often described primarily in economic terms, an approach that many geographers now argue is 'too simplistic to explain observed migrations' (Boyle et al. 1998, 67). A second reason is that it often makes assumptions about the beliefs and behaviours of migrants, without making any effort to examine those assumptions other than through an examination of migration patterns. Those working with push-pull models are often acutely aware of their limitations. Dorigo and Tobler (1983), for example, wrote that they could not claim 'to have explained why people migrate; we can only assert a tolerably good description of the spatial pattern' (p. 14). Despite these types of nuances, the quantitative reduction of migration into equations, formulae and prediction created significant unease in the middle of geography's cultural turn. This unease led to a re-examination of how geographers theorize and research migration, particularly within population geography. Traditionally, migration - along with fertility and mortality was the focus of study for population geographers. However, the lack of engagement of population geography with social theory was noted as a concern (McHugh 2000), and there were calls for studies of migration within population geography to move out of an empiricist and essentialist trap. Now, migration has come to dominate population geography (Boyle 2002, 531), and studies of migration within geography have developed beyond narrowly defined demographics.

\section{Geography and Migration: Questions of Identity}

In recent years, geographers who research migration have become more interested in the subjective experiences of individual migrants, and how those experiences are shaped by and in turn shape migrant identities. This mirrors a broader emphasis on identity within geography, ranging from questions of gender, race, ethnicity, class and sexuality (see, for example, Blunt and Wills 2000; Mitchell 2000; Rose 1993) to more normative categories of multiculturalism and cosmpolitanism (see Mitchell 2004b, 2006, 2007 for good overviews). The development of feminist geography, with the related expansion of methodological approaches to geography, has underpinned much of this shift in focus. In particular, a range of 
qualitative techniques - including ethnography, in-depth interviews, biographical approaches and participant observation - has been increasingly used in geographical studies of migration.

From the 1980s onwards, feminist approaches to the study of migration developed in a range of disciplines. A special issue of International Migration Review in 1984, edited by Mirjana Morokvasic, explicitly addressed the presence of migrant women in labour forces, despite the fact that their work 'is poorly assessed by the official data and not always recognized as an economic activity at all' (p. 887). In this, Morokvasic included domestic work, petty trade, work at home and prostitution as examples of work that failed to be counted or considered as such. The special issue was thus concerned with making women visible in migration research, a struggle that continues today. A recent example of this is the attempts to reconsider the experiences of skilled female migrants. As Kofman pointed out in 2000, skilled female migrants were invisible in studies of skilled migration to Europe, while Raghuram (2008) has recently highlighted the lack of attention to female migrants working in male-dominated sectors. Allied to attempts to make women visible in migration research was the development of a more nuanced understanding of gender as socially produced rather than as biologically determined. Just as gender shifts and changes meaning through migration, so also do other aspects of identity, such as race, ethnicity and sexuality. This is exemplified by research on the St. Patrick's Day Parade in New York, where recent gay and lesbian migrants from Ireland have been denied permission to take part in the parade. Their public expression of sexuality is problematic for the parade organizers, who see this as a challenge to their understanding of Irish identity (Marston 2001). Geographic research into the social (re)production of these various identities, in and through migration, was thus enabled by advances in feminist approaches.

Stories - in particular, migrant stories - have become a favoured way to address the interplay of identity and migration (Halfacree and Boyle 1993; Lawson 2000). These are not the popular fictionalized stories of migration and identity (see, for example, Levy 2004), but rather the stories told by migrants about their migrant lives or the stories told by researchers about their direct or indirect encounters with migrants. Recent studies of return migrants to Ireland pay particular attention, through a narrative approach, to questions of identity (Corcoran 2002; Ní Laoire 2007, 2008). For example, Ní Laoire (2008) uses a biographical and life-course approach in interviewing migrants who had returned to Ireland in the late 1990s and early 21st century. Through this approach, she highlights 'the ways in which return migrants construct their own narratives of return' (p. 198). The voices of the return migrants are given prominence. Michelle, who returned to Ireland from Britain, said 'there was always a piece of me that would prefer to be known to be Irish than to be English, and I felt that if we stayed there that the children would 
grow up and they would be English really and I didn't really want that. I wanted them to be Irish . . .' (in Ní Laoire 2008, 203). A different, though related, approach is taken by Heather Merrill in her rich ethnographic study of migrants in Turin, Italy (Merrill 2006). Over the course of a decade, Merrill spent time in Turin, watching and taking part in the transformation of the city by immigrants, locals, capital and the state. She was particularly interested in Alma Mater, a grassroots women's organization that developed in Turin, and that was explicitly international, interethnic and anti-racist. Alma Mater includes and involves migrant women and Italian feminists, although its main focus is migrant women, and its main goal is to provide a physical space for cultural exchange, employment and training opportunities, and social events and activities (Merrill 2006, 18). Despite the efforts to create a safe and inclusive space in Alma Mater, difficulties and tensions arise because of the intersection of various identities, most notably race, class and nationality. However, outside Alma Mater, these significant differences between migrant women are often erased in a society that constructs migrant women as a distinct and homogenous category. This category of migrant woman - socially constructed, contingent and undifferentiated - may result in experiences of marginalization, exclusion, vulnerability and hostility. Those experiences may, in turn, affect the identities of women migrants.

Merrill's ethnographic account is firmly grounded in a particular place, Alma Mater and Turin, albeit in the context of global economic restructuring and changes in patterns of international migration. Other recent work within geography on the relationship between migration and identity focuses on transnationalism - on the ways in which migrants are intimately and intricately involved in social, political and economic networks that stretch across national boundaries. One such account is provided by Katharyne Mitchell in her work on the transnational elites who moved from Hong Kong to Vancouver in the 1980s and 1990s (see Mitchell 2001, 2004a). Mitchell was particularly interested in exploring how these wealthy business migrants operated as 'global economic subjects' (Ong 1993 in Mitchell $2001,170)$. The study of transnationalism has often focused on such elite transmigrants, who are able to bypass more restrictive immigration legislation because of their access to capital (Mitchell 2003). It has focused on the new social geographies created by transmigrants, such as astronaut families, satellite kids and expatriate enclaves (Beaverstock 2002; Ley 2004). However, studies of transnationalism have also focused on flows of money, information and goods, and on the political involvement of transmigrants, particularly through diasporic networks (Crush and McDonald 2002; Kelly and Lusis 2006; Mains 2007; Mavroudi 2008; Olson and Silvey 2006).

The preoccupations of transnationalism - mutable identities, multiple connections, global networks - suggest strong links with feminist work on migration. Yet, many feminists have highlighted an uneasy relationship between the two. As Pratt and Yeoh (2003) have pointed out, much 
scholarly work on transnationalism is implicitly gendered as masculinist (p. 159). In many ways, the hypermobile subject of transnationalism echoes the similarly gendered colonial explorer of the past. Gender-blind transnationalism has been targeted in a variety of ways. This includes attention to the feminization of migration and to the specific productive and reproductive roles of female migrants. For example, women migrants often gain work through the global care chain - as domestic or sex workers or as caregivers (Hochschild and Ehrenreich 2002). This is a component of what Saskia Sassen describes as the 'counter-geographies of globalization' (Sassen 2000, 523). These counter-geographies are the circuits of activities that women are increasingly involved in, to ensure survival for themselves and their families, particularly through their growing role in the shadow economy. Counter-geographies lead to new transnational connections. For example, women are separated from their children, who remain in their home country, often cared for by female relatives. Through their economic activities, these migrant women provide financial support for their families and their home countries, particularly in the form of remittances. In the process, their gender identities are often reformed and reshaped, highlighting the 'co-constructed nature of identities and places' (Silvey 2006). The growing body of research on transnational women (Boyle 2002) goes some way to addressing the complexities of the relationship between migration and identity, particularly in the context of the seductiveness of transnational approaches.

\section{The Politics and Practice of Belonging}

The concept of belonging offers geographers a way to ground the relationship between migration and identity. It also uncovers its own challenges, particularly through its erection of barriers, policing of borders and practice of exclusion. For this reason, geographers - particularly critical geographers - have been at pains to highlight the ways in which the bodies of migrants are used as a means to exclusionary practices at a range of scales. Geographers have also highlighted the various strategies for belonging employed by migrants, particularly the 'topographies of home and homemaking' (Staeheli and Nagel 2006, 1600) that construct home within a network of material and symbolic relationships.

A recurring theme in this regard is the way in which immigrants become the focus of exclusionary nationalist politics. In a powerful and compelling account of the development of racism in Sweden, Allan Pred shows the ways immigrants become the repository of feelings of fear, insecurity, confusion and frustration for the indigenous population at times of significant change. As he poetically declares (Pred 2000, 30-31),

Under circumstances in which the highly familiar grows more and more unfamiliar,

the resulting amalgam of insecurity and dis-ease, 
of confusion and festering frustration,

the resulting desire for remooring,

is readily worked by many into a reassertion

of national (regional/local) symbols/meanings/values/idea-logics,

by way of a reassertion of difference,

is readily worked into discourses and practices

apt to focus on those who culturally and physically embody

the newly unfamiliar,

apt to victimize those 'less advanced,' 'unmodern'

migrants, refugees, or minorities

who most readily serve as scapegoats

for all that is newly unfamiliar,

for every thing and every relation that is newly different,

newly ununderstood,

or newly unappreciated.

Pred's text is suffused with surprise and disappointment that Sweden, with its long tradition of equality and social justice, should now be experiencing cultural racism. At the same time, it is compelled by a desire to explain the appearance and acceleration of cultural racism, to show how space is implicated in racism, and to demonstrate how the imagined past - "when Sweden was really Swedish' (Pred 2000, 188) - is used to deny or forget the unsettling present. Koefoed and Simonsen (2007) describe a similar set of processes at work in Denmark, where uncertainties about the meaning of Danishness are increasingly juxtaposed against the presence of immigrants and refugees.

Citizenship is one of the tools of inclusion and exclusion used by states to cope with the perceived threat of mobile migrants. As Tim Cresswell (2006) comments, "citizens require the production of others to be possible, and the definition of citizen carries around the noncitizen or the shadow citizen as part of its constitution' (p. 161). Examples of the shadowy figure of the non-citizen or not-quite citizen abound: they include 'foreigners' in Switzerland (Riaño and Waslt-Walter 2006), immigrants in post-apartheid South Africa (Dodson and Oelofse 2002; Reitzes and Bam 2002), Arab immigrants and Americans of Arab descent in the USA (Staeheli and Nagel 2006) and Turkish immigrants in Germany (Ehrkamp 2006). At such times, citizenship becomes the marker of belonging, a way of rearticulating national identity through the exclusion of those who are not citizens (Cresswell 2006, 189). The processes of exclusion vary. Ireland provides an explicit example of the use of citizenship as a marker of exclusion. There, in 2004, the basis of citizenship was changed as a response to the perceived threat of so-called 'citizenship tourists' - pregnant women who came to Ireland to give birth to their children (White and Gilmartin forthcoming). Other examples are perhaps less explicit, but similarly serve to mark the difference between the citizen and the less-than citizen. For example, discourses of self-segregation and parallel lives in relation to British Muslims raise questions about Britishness, identity, and 
Muslims as other (Phillips 2006). Similarly, attempts to build mosques in Sydney resulted in conflict, and those who were opposed to the mosques made claims to local citizenship as a means of legitimating their opposition (Dunn 2003).

Despite claims of the demise of the nation-state as a consequence of globalization, state responses to the question of belonging illustrate its ongoing power and reach. While states may have lost ground to transnational capital, migrant bodies represent a significant site for their articulation of national identity. In addition to the legal and symbolic form of citizenship, states are also engaged in material and legislative border enforcement, and in the creation of hierarchies of immigrants with differential rights and entitlements. For example, recent research has highlighted new anxieties about borders and border policing in the US South. Southern states have significantly expanded their immigration and border enforcement programmes (Coleman 2007) and supported a range of anti-immigrant legislation in the aftermath of 9/11 (Winders 2007), while the European Union has increasingly intensified control of its borders (Collyer 2007; van Houtum and Pijpers 2007; Samers 2004). Geographers have also highlighted the ways in which states prioritize particular groups or classes of immigrants: facilitating the paths to belonging for (some) skilled workers and entrepreneurs, while creating obstacles and difficulties for other workers, family members, asylum seekers and particular nationalities (Ball and Piper 2002; Kofman 2002). As Kofman (2005) has highlighted, states are 'increasingly differentiating between the economically useful and performative, that is the skilled, and those who are supposedly not useful, the unskilled, who may be seen as problematic and dangerous for social order and stability' (p. 87). This, in turn, may lead to citizenship exploitation, the use of citizenship as a justification for differential treatment of workers and denizens (Bauder 2007). While an increasing number of sending and receiving states are now recognizing dual citizenship (Leitner and Ehrkamp 2006), this is contemporaneous with restrictions on citizenship for the majority of migrants. The mobility and belonging of idealized migrants - based on class, race, gender and sexuality - is facilitated (Bell and Binnie 2006; Simmons 2008), while other migrants have to suffer regulation, surveillance and control.

Confronted with restrictions, suspicion and hostility, how might migrants address the broader questions of belonging and identity? One possibility is suggested by Staeheli and Nagel, who offer the contradictory concept of home. As they write, 'in leaving home, immigrants must make a new home, and they must negotiate the contradictions of both homes, even as they may feel they belong to neither' (Staeheli and Nagel 2006, 1599). The practice of home-making has been studied in a variety of contexts. Tolia-Kelly (2004) shows how the visual and material cultures and objects in British Asian homes help to create 'new textures of home' while at the same time materializing memories of other homes and other 
places of belonging (p. 676; Tolia-Kelly 2006). Walton-Roberts and Pratt (2005) outline the different meanings of home for the members of one transnational migrant family, located between South India and Canada. The younger son of the family told the researchers, 'I don't consider home anything now. So I've given up the idea of home' (in Walton-Roberts and Pratt 2005, 190). Meanwhile, his mother has re-established her home in Canada, while other family members move between homes in Canada and south India. Home is also constructed through participation: in community activism, or in festivals and celebrations. For example, the Canadian Hispanic Day Parade offers a space for the articulation of a Latin American identity in Toronto (Veronis 2006). In their study of Arab Americans, Staeheli and Nagel identify homes that are place-based as well as deterritorialized, and they understand homes as material and metaphorical spaces that are full of shifting meanings (Staeheli and Nagel 2006). They argue that for their respondents, the multiple locations of home enriched their sense of belonging in the USA. However, the concept of home is not just celebratory and productive of belonging. It also marks difference, with immigrants in hostile societies regularly told by natives to go 'back home'.

The study of belonging has been further expanded in the context of the so-called 'new mobilities' paradigm within the social sciences (Sheller and Urry 2006). Arguing that mobilities have to be understood in terms of their interdependence rather than as separate spheres (Sheller and Urry 2006, 212), an agenda for the study of migration would thus involve 'examining many consequences for different peoples and places located in what we might call the fast and slow lanes of social life' (Hannam et al. 2006, 11). Geographers have long been attuned to the innovations outlined in these various manifestos for mobility research: to place as dynamic, to the power-geometries of place, and to the dialectical relationship between people and place. However, geographers have recently attempted to develop an alternative understanding of the relationship between mobility and belonging through the concept of translocalism. This draws on the work of Appadurai, who used the term 'translocality' to identify the ways in which communities are spatially extended by virtue of migration; where 'social architecture and relational topologies have been refigured on a transnational basis' (Conradson and Mckay 2007, 168). In their introduction to a journal special issue on the topic, Conradson and Mckay (2007) use this as a starting point from which to articulate their understanding of 'translocal subjectivities' (p. 168). In this way, they challenge the prioritization of the 'nation' that characterizes transnational theorizations; they insist that migrant subjects are multiply located and placed, with strong senses of attachment and responsibility to family, friends and place; and they assert the importance of emotions and feelings in understanding both mobility and emplacement in social life.

Geographers have developed the concept of translocal subjectivities in a variety of ways. Mckay's study of a Filipino family, located in Hong 
Kong and the Ifugao Province in the Philippines, shows how they remain connected through money transfers and gifts, through telephone calls and text messages, and through meeting and exceeding expectations and obligations (Mckay 2007). She describes this as a 'translocal field of intimacy [that] elaborates on previous co-present relations' (Mckay 2007, 191). Rachel Silvey's study of Indonesian migrants to Saudi Arabia illustrates how "families, employers, recruiters, nations, and religious "communities" all compete for the loyalty, labor, and emotional affinity of migrant women' (Silvey 2007, 227), and how they use discourses of gendered morality and piety, often framed in terms of fear, love and disgust, as part of the tools of competition. According to Conradson and Latham (2007), the affective possibilities of London - the ways in which the city facilitates particular kinds of embodied feelings - help to make it attractive to middle-income and skilled migrants from New Zealand. In contrast, Huang and Yeoh (2007) discuss maid abuse - the emotional and physical abuse of domestic workers in Singapore - and the ways in which it disrupts the notion of the home as a safe space, particularly for migrant workers who are already emotionally dislocated (p. 212). Taken together, these papers represent a sustained effort to engage with emotional aspects of both migration and belonging, although their characterization of the 'translocal' is partial and fluid.

\section{The Place of Migration}

'The nature of transnationalism is dramatically affected by place, to which there has been too little attention paid,' argues Kevin Dunn (2008), in the introduction to a special issue on comparative transnationalism (p. 4). Dunn's observation is apposite since, in the rush to theorize transnationalism within geography, the importance of place is often marginalized. There are some recent exceptions which attempt to again foreground place, and to retheorize migration from a place-based perspective. For example, Marie Price and Lisa Benton-Short (2008) redefine global cities on the basis of immigrant populations rather than on the more conventional measures, such as the presence of advanced producer services. Defining global cities in this way creates a rather different urban hierarchy: cities with extremely high proportions of immigrants that would not feature on a traditional global city list include Dubai, Amsterdam, Muscat, Geneva, Tel Aviv and Kiev (Benton-Short et al. 2005, 953). These 'immigrant gateways' function within a broader global network of cities and, in doing so, create new urban spaces and new global linkages (Price and Benton-Short 2008). Studying immigrant gateways thus provides an important theoretical contribution to our understanding of global cities, retheorizes migration from an urban perspective, and seeks to understand immigrant gateways as specific places that in turn serve to shape global migration patterns. 
An alternative place-based study focuses on Latino migration to the US South (Smith and Furuseth 2006). With the exception of Florida, the US South $^{1}$ traditionally contained very few established Latino communities. This began to change in the 1990s, and the Hispanic population in the region increased from 3.8\% in 1990 to $7.9 \%$ in 2004 (Furuseth and Smith $2006,5)$. In focusing on the US South, the emphasis is on how specific places are changing because of Latino migration. However, Latino migration and migrants are just one aspect of a broader process of transition, an aspect that is itself linked to changes in other places. The complexities of these interconnections are well illustrated by a chapter on rural restructuring in the US South (Torres et al. 2006). This focuses on macro-scale factors, for example, neo-liberal economic restructuring in Mexico, the active exclusion of immigrants from traditional US destinations, and US immigration reform in the 1980s. These factors, allied with rural development and restructuring in North Carolina, have helped to create the conditions for Mexican migration in particular to rural counties in the state. The presence of Latinos has been widely, if quietly, accepted in these rural areas, and Latinos are on balance happy to live in rural areas despite lower wages and limited assistance or support (Torres et al. 2006, 59-60). Yet, broader anti-immigrant sentiments in the USA are affecting Latinos in these rural areas, and political organizing and advocacy by Latinos also serves to unsettle their tacit acceptance by local residents. In addition, day-today interactions between Latinos and their White and African American neighbours are disrupting the traditional Black/White bifurcation in the US South and raising broader questions about inclusion, acceptance and hospitality. These questions are further explored by Smith and Winders (2008), who highlight the conflict between the flexible mobile bodies demanded by neo-liberalism, and the demands of those bodies for places of their own. As they ask, "what happens when acts of "living" transform the temporally flexible, spatially mobile immigrant body at work into the placed, rooted, but nonetheless "alien" body at home and on the streets of the southern heartland?' (Smith and Winders 2008, 61). This conflict - between mobility and belonging - is at the heart of the study of migration in place.

\section{Conclusions}

The study of migration in geography takes numerous forms and moves in numerous directions. The complexity of migration and its changing form in the contemporary world demands such heterogeneity in its study (Castles and Miller 2003; King 2002). Prominent strands of research include the quantification of migration, migration modelling, the classification of migrants, the settlement patterns of migrants, ethnic residential concentration and migrant remittances. However, this article focuses on the development of a particular strand of research, focusing on the relationship between migration, identity and belonging. 
There is much to celebrate in the ways in which the relationship between migration, identity and belonging is being studied by geographers. The first is methodological, with a significant expansion in the ways in which migration is narrated. Migrant stories are at the root of much of this research, with interviews, focus groups, life histories, photographs and other forms of material culture used to illuminate the experience of migrants and the patterns and processes of migration. The second is theoretical, particularly in relation to questions of identity and belonging. In this way, studies of citizenship, transnationalism, translocalism and home serve to highlight the complexities of the relationship between mobility and emplacement. However, these new emphases often serve to marginalize other approaches to the study of migration. For example, the political economy of migration often serves as a backdrop against which personal migrant narratives are played out, rather than as an active participant in shaping the relationship between migration, identity and belonging. Similarly, the power geometries of migration, in the bodies of mobile elites and marginalized workers who are placed in post-colonial national hierarchies, remain undertheorized. And, as identities are foregrounded, place gets relegated. As a result, the 'moral geographies' (Cresswell 2006, 177) of place and migration are often implicit rather than explicit.

The relationship between migration, identity and belonging stretches across place and time. The challenge, for geographers, is to interrogate the ways in which this relationship alters and changes across a variety of mutually constitutive scales. Rebecca Solnit (1998) has written that place, despite its apparent solidity, is 'made up of a continuous flow of discontinuities and accelerating movements' (p. 132). Similarly, Doreen Massey (2005) has argued that place is an event, characterized by its 'throwntogetherness' in a way that demands negotiation (p. 141). Migration is one such event, discontinuity and movement, but one that may also be characterized by the desires for mooring and grounding. In addressing these links and disjunctures between migration, identity and belonging, place emerges as a central site for the investigation of transformation at a multiplicity of interlocking scales.

\section{Short Biography}

Mary Gilmartin is a lecturer in Department of Geography at the National University of Ireland Maynooth. Her current research focuses on migration, particularly contemporary migration to Ireland. She is currently involved in a number of research projects relating to this issue, such as a study of experiences of integration among recent immigrants to Ireland (with colleagues from University College Dublin). Recent publications on this topic include a special issue of Irish Geography (co-edited with Allen White) and book chapters on race and racism in Ireland (with Úna Crowley and Rob Kitchin) and on Dublin as an immigrant gateway. In 
addition to research on migration, she also publishes on the nature and practice of geography. She holds an $\mathrm{MA}$ and a $\mathrm{PhD}$ from the University of Kentucky.

\section{Notes}

* Correspondence address: Mary Gilmartin, Department of Geography, National University of Ireland Maynooth, Maynooth Co., Kildare, Ireland. E-mail: mary.gilmartin@nuim.ie.

${ }^{1}$ For the purposes of this volume, the US South includes Kentucky, Tennessee, Virginia, North Carolina, South Carolina, Georgia, Alabama, Mississippi, Louisiana and Arkansas.

\section{References}

Ball, R., and Piper, N. (2002). Globalisation and regulation of citizenship: Filipino migrant workers in Japan. Political Geography 8, pp. 1013-1034.

Bauder, H. (2007). What a difference citizenship makes! Migrant workers in rural Ontario. In: Graham, K. (ed.) Our diverse cities: Ontario, vol. 4. [online]. Retrieved on 10 March 2008 from: http://canada.metropolis.net/pdfs/ODC\%20Ontario\%20Eng.pdf

Beaverstock, J. V. (2002). Transnational elites in global cities: British expatriates in Singapore's financial district. Geoforum 33 (4), pp. 525-538.

Bell, D., and Binnie, J. (2006). Geographies of sexual citizenship. Political Geography 25 (8), pp. 869-873.

Benton-Short, L., Price, M., and Friedman, S. (2005). Globalization from below: the ranking of global immigrant cities. International Journal of Urban and Regional Research 29 (4), pp. 945-959.

Blunt, A., and Wills, J. (2000). Dissident geographies: an introduction to radical ideas and practices. Harlow, UK: Prentice Hall.

Boyle, P. (2002). Population geography: transnational women on the move. Progress in Human Geography 26 (4), pp. 531-543.

Boyle, P., Halfacree, K., and Robinson, V. (1998). Exploring contemporary migration. Harlow, UK: Pearson Education.

Castles, S., and Miller, M. J. (2003). The age of migration: international population movements in the modern world, 3rd ed. Basingstoke, UK: Palgrave Macmillan.

Coleman, M. (2007). Immigration geopolitics beyond the US-Mexico border. Antipode 39 (1), pp. 54-76.

Collyer, M. (2007). In-between places: trans-Saharan transit migrants in morocco and the fragmented journey to Europe. Antipode 39 (4), pp. 668-690.

Conradson, D., and Latham, A. (2007). The affective possibilities of London: antipodean transnationals and the overseas experience. Mobilities 2 (2), pp. 231-254.

Conradson, D., and McKay, D. (2007). Translocal subjectivities: mobility, connection, emotion. Mobilities 2 (2), pp. 167-174.

Corcoran, M. (2002). The process of migration and the reinvention of self: the experiences of returning Irish emigrant. Éire-Ireland 37 (1-2), pp. 175-191.

Cresswell, T. (2006). On the move: mobility in the modern western world. New York: Routledge.

Crush, J., and McDonald, D. A. (eds) (2002). Transnationalism and new African immigration to South Africa. Kingston, Canada: Southern African Migration Project.

Dodson, B., and Oelofse, C. (2002). Shades of xenophobia: in-migrants and immigrants in Mizamoyethu, Cape Town. In: Crush, J. and McDonald, D. A. (eds) Transnationalism and new African immigration to South Africa. Kingston, Canada: Southern African Migration Project, pp. 124-148.

Dorigo, G., and Tobler, W. (1983). Push-pull migration laws. Annals of the Association of American Geographers 73 (1), pp. 1-17.

Dunn, K. (2003). Using cultural geography to engage contested constructions of ethnicity and citizenship in Sydney. Social and Cultural Geography 4 (2), pp. 153-165. 
(2008). Guest Editorial - Comparative analyses of transnationalism: a geographic contribution to the field. Australian Geographer 39 (1), pp. 1-7.

Ehrkamp, P. (2006). 'We Turks are no Germans': assimilation discourses and the dialectical construction of identities in Germany. Environment and Planning A 38 (9), pp. 1673-1692.

Ehrkamp, P., and Leitner, H. (2006). Rethinking immigration and citizenship: new spaces of migrant transnationalism and belonging. Environment and Planning A 38, pp. 1591-1597.

Fureseth, O., and Smith, H. (2006). From Winn-Dixie to tiendas: the remaking of the New South. In: Smith, H. and Furuseth, O. (eds) Latinos in the New South: transformations of place. Aldershot, UK: Ashgate, pp. 1-17.

Halfacree, K., and Boyle, P. (1993). The challenge facing migration research: the case for a biographical approach. Progress in Human Geography 17, pp. 333-348.

Hannam, K., Sheller, M., and Urry, J. (2006). Editorial: mobilities, immobilities and moorings. Mobilities 1 (1), pp. 1-22.

Hochschild, A., and Ehrenreich, D. (eds) (2002). Global woman: nannies, maids and sex workers in the new economy. New York: Owl Books.

van Houtum, H., and Pijpers, R. (2007). The European Union as a gated community: the two-faced border and immigration regime of the EU. Antipode 39 (2), pp. 291-309.

Huang, S., and Yeoh, B. S. A. (2007). Emotional labour and transnational domestic work: the moving geographies of 'maid abuse' in Singapore. Mobilities 2 (2), pp. 195-217.

Kelly, P., and Lusis, T. (2006). Migration and the transnational habitus: evidence from Canada and the Philippines. Environment and Planning $A$ 38, pp. 831-847.

King, R. (2002). Towards a new map of European migration. International Journal of Population Geography 8, pp. 89-106.

Koefoed, L., and Simonsen, K. (2007). The price of goodness: everyday nationalist narratives in Denmark. Antipode 39 (2), pp. 310-330.

Kofman, E. (2000). The invisibility of skilled female migrants and gender relations in studies of skilled migration in Europe. International Journal of Population Geography 6, pp. 1-15.

- (2002). Contemporary European migrations, civic stratification and citizenship. Political Geography 21, pp. 1035-1054.

- (2005). Figures of the cosmopolitan: privileged nationals and national outsiders. Innovation 18 (1), pp. 83-97.

Lawson, V. A. (2000). Arguments within geographies of movement: the theoretical potential of migrants' stories. Progress in Human Geography 24 (2), pp. 173-189.

Leitner, H., and Ehrkamp, P. (2006). Transnationalism and migrants' imaginings of citizenship. Environment and Planning A 38, pp. 1615-1632.

Levy, A. (2004). Small island. London: Review.

Ley, D. (2004). Transnational spaces and everyday lives. Transactions of the Institute of British Geographers 29, pp. 151-164.

Mains, S. (2007). Hurricanes in Toronto: distance, identity, and the Jamaican diaspora. Focus on Geography 50 (1), pp. 1-8.

Marston, S. (2001). Making difference: conflict over Irish identity in the New York City St. Patrick's Day Parade. Political Geography 21 (3), pp. 373-392.

Massey, D. (2005). For space. London: Sage Publications.

Mavroudi, E. (2008). Palestinians in diaspora, empowerment and informal political space. Political Geography 27, pp. 57-73.

McHugh, K. E. (2000). Inside, outside, upside down, backward, forward, round and round: a case for ethnographic studies in migration. Progress in Human Geography 24, pp. 71-89.

Mckay, D. (2007). 'Sending dollars shows feeling': emotions and economies in Filipino Migration. Mobilities 2 (2), pp. 175-194.

Merrill, H. (2006). An alliance of women: immigration and the politics of race. Minneapolis, MN: University of Minnesota Press.

Mitchell, D. (2000). Cultural geography: a critical introduction. Oxford, UK: Blackwell.

Mitchell, K. (2001). Transnationalism, neo-liberalism, and the rise of the shadow state. Economy and Society 30 (2), pp. 165-189.

- (2003). Cultural geographies of transnationality. In: Anderson, K., et al. (eds) Handbook of cultural geography. London: Sage, pp. 74-87. 
. (2004a). Crossing the neoliberal line: pacific rim migration and the metropolis. Philadelphia, PA: Temple University Press.

- (2004b). Geographies of identity: multiculturalism unplugged. Progress in Human Geography 28 (5), pp. 641-651.

- (2006). Geographies of identity: the new exceptionalism. Progress in Human Geography 30 (1), pp. 95-106.

- (2007). Geographies of identity: the intimate cosmopolitalism. Progress in Human Geography 31 (5), pp. 706-720.

Morokvasic, M. (1984). Birds of passage are also women. International Migration Review 18 (4), pp. 886-907.

Ní Laoire, C. (2007). The 'green green grass of home': return migration to rural Ireland. Journal of Rural Studies 23 (3), pp. 332-344.

- (2008). 'Settling back'? A biographical and life-course perspective on Ireland's recent return migration. Irish Geography 41 (2), pp. 195-210.

Olson, E., and Silvey, R. (2006). Transnational geographies: rescaling development, migration, and religion. Environment and Planning A 38, pp. 805-808.

Phillips, D. (2006). Parallel lives? Challenging discourses of British Muslim self-segregation. Environment and Planning D 24, pp. 25-40.

Pratt, G., and Yeoh, B. (2003). Transnational (counter) topographies. Gender, Place and Culture 10 (2), pp. 159-166.

Pred, A. (2000). Even in Sweden: racisms, racialized spaces, and the popular geographical imagination. Berkeley, CA: University of California Press.

Price, M., and Benton-Short, L. (eds) (2008). Migrants to the metropolis: the rise of immigrant gateway cities. Syracuse, Italy: Syracuse University Press.

Raghuram, P. (2008). Migrant women in male-dominated sectors of the labour market: a research agenda. Population, Space and Place 14, pp. 43-57.

Ravenstein, E. (1885). The laws of migration. Journal of the Statistical Society of London 48 (2), pp. 167-235.

Reitzes, M., and Bam, S. (2002). Citizenship, immigration, and identity in Winterveld, South Africa. In: Crush, J. and McDonald, D. A. (eds) Transnationalism and new African immigration to South Africa. Kingston, Canada: Southern African Migration Project, pp. 80-100.

Riaño, Y., and Wastl-Walter, D. (2006). Immigration policies, state discourses on foreigners, and the politics of identity in Switzerland. Environment and Planning A 38 (9), pp. 1693-1713.

Rose, G. (1993). Feminism and geography: the limits of geographical knowledge. London: Polity.

Samers, M. (2004). An emerging geopolitics of 'illegal' immigration in the European Union. European Journal of Migration and Law 6, pp. 27-45.

Sassen, S. (2000). Women's burden: counter-geographies of globalization and the feminization of survival. Journal of International Affairs 53 (2), pp. 503-524.

Sheller, M., and Urry, J. (2006). The new mobilities paradigm. Environment and Planning A 38 (2), pp. 207-226.

Silvey, R. (2006). Geographies of gender and migration: spatializing social difference. International Review of Migration 40 (1), pp. 64-81.

- (2007). Mobilizing piety: gendered morality and Indonesian-Saudi transnational migration. Mobilities 2 (2), pp. 219-229.

Simmons, T. (2008). Sexuality and immigration: UK family reunion policy and the regulation of sexual citizens in the European Union. Political Geography 27, pp. 213-230.

Smith, B. E., and Winders, J. (2008). 'We're here to stay': economic restructuring, Latino migration and place-making in the US South. Transactions of the Institute of British Geographers 33 , pp. 60-72.

Smith, H., and Furuseth, O. (eds) (2006). Latinos in the new South: transformations of place. Aldershot, UK: Ashgate.

Solnit, R. (1998). A book of migrations: some passages in Ireland. London: Verso.

Staeheli, L., and Nagel, C. (2006). Topographies of home and citizenship: Arab-American activists in the United States. Environment and Planning A 38, pp. 1599-1614.

Tolia-Kelly, D. (2004). Materializing post-colonial geographies: examining the textual landscapes of migration in the South Asian home. Geoforum 35, pp. 675-688. 
(2006). Mobility/stability: British Asian cultures of 'landscape and Englishness'. Environment and Planning $A$ 38, pp. 341-358.

Torres, R. M., Popke, E. J., and Hapke, H. M. (2006). The south's silent bargain: rural restructuring, Latino labor and the ambiguities of migrant experience. In: Smith, H. and Furuseth, O. (eds) Latinos in the new south: transformations of place. Aldershot, UK: Ashgate, pp. 37-67.

Veronis, L. (2006). The Canadian Hispanic Day Parade, or how Latin American immigrants practise (sub)urban citizenship in Toronto. Environment and Planning A 38, pp. 1653-1671.

Walton-Roberts, M., and Pratt, G. (2005). Mobile modernities: a South Asian family negotiates immigration, gender and class in Canada. Gender, Place and Culture 12 (2), pp. 173-195.

White, A., and Gilmartin, M. (in press). Critical geographies of citizenship and belonging in Ireland. Women's Studies International Forum.

Winders, J. (2007). Bringing back the (b)order: post-9/11 politics of immigration, borders and belonging in the contemporary US South. Antipode 39 (5), pp. 920-942. 